Luz Neira

\title{
Medusa en los mosaicos romanos: de la mirada que petrificaba a una mirada apotropaica' $^{1}$
}

Palabras clave: Antigüedad, mitos, mirada, Medusa, valor apotropaico, mosaicos romanos, domus, villae

DOI: 10.4312 ars.9.1.32-57

\section{Introducción a la mirada en el mito}

La mirada en la representación de episodios mitológicos responde a una gran diversidad, acorde a la variedad de las distintas leyendas en las que la mirada es esencial. En este sentido, tanto desde un punto de vista iconográfico como conceptual y simbólico son muy diferentes las miradas plasmadas. Miradas correspondidas, miradas de quién mira sin ser visto, miradas prohibidas, la consecuencia de una de estas miradas sin que la mirada aparezca de modo explícito ..., e incluso la mirada como recurso visual que, a su vez, atrae la mirada del espectador hacia el personaje o los personajes objeto de atención. En todas ellas, es protagonista tanto quien mira como quien es mirado.

Miradas correspondidas, como en algunas representaciones del Rapto de Europa, a lomos del bello toro blanco en el que se ha metamorfoseado Zeus, en alusión a la atracción sentida en una playa de la patria fenicia de la princesa, que, tras una intensa travesía marina culminaría después con la unión hierogámica en la isla de Creta y con el consiguiente nacimiento, al menos, de Minos, rey mítico y epónimo del mundo minoico. Una leyenda etiológica que, simbolizando el reconocimiento de los griegos al préstamo fenicio, evoca el surgimiento de la civilización en el continente, denominado a partir de este episodio como Europa, y que resaltaba, en aquel proceso, el papel pionero de Creta (Wattel de Croizant, 1997; López Monteagudo, San Nicolás, 2013).

Miradas de quién mira sin ser visto, de las que son imágenes muy elocuentes, y similares desde el punto de vista iconográfico, las escenas protagonizadas por Dioniso y Ariadna y Marte e Ilia/Rea Silvia. En el caso de Ariadna, la joven cretense, al haberse quedado dormida y ser abandonada por Teseo en la isla de Naxos, es descubierta por

1 Este trabajo es resultado de la investigación desarrollada en el marco del Proyecto europeo de Cultura Crossing Stages (2013-2015), liderado por la UC3M. 
Dioniso, o por un sátiro de su cortejo que levanta incluso el vestido de la joven con el fin de mostrársela al dios (San Nicolás, 2013, figs. 54-59); así como el sobrevuelo de Marte por el Lacio contemplando a la bella vestal que, habiendo ido en busca de agua, se había quedado dormida a orillas del Tíber (Neira, 2005; Neira, 2009).

En ambas escenas, el sueño de Ariadna e Ilia/Rea Silvia es sinónimo de su inconsciencia, ingenuidad e inocencia ${ }^{2}$, ya que en particular en el caso de Ilia/Rea Silvia su sueño la salva de cualquier atisbo de consentimiento a la unión carnal de la que nacerían Rómulo y Remo, pues ¡cómo iba a ser el futuro fundador de Roma hijo de una vestal que hubiera incumplido el voto de castidad! De este modo se garantizaban los nobles orígenes genealógicos que remontaban a Troya, pero sin manchar la imagen de la madre.

Miradas prohibidas, con fatales consecuencias, como la del «voyeur» Acteón, convertido en ciervo por la afrenta de mirar a la diosa mientras disfrutaba del baño, en compañía de las ninfas (LIMC I, 1981, Acteón), como imagen expresiva del mito como fórmula de control social sobre el que volveremos más adelante.

E incluso la consecuencia misma de una de estas miradas prohibidas, como pueda ser la propia imagen de Acteón, ya convertido en ciervo, mientras es devorado por sus propios perros (LIMC 1, 1981, Acteón; Mourao, 2014, 199-200, fig. 74), si bien, según una tradición recordada por Pausanias (Descripción de Grecia, IX, 34, 4), Acteón de alguna manera sobrevive en la estatua que el centauro Quirón modela para consolar a sus perros, ya que en Orcomene (Arcadia), el oráculo ordenó buscar todos los restos de Acteón, darles sepultura y hacer una figura de bronce, a la que cada año se dedicaban sacrificios fúnebres.

E incluso la mirada como recurso visual que, a su vez, atrae la mirada del espectador hacia el personaje o los personajes objeto de atención, entre cuyos ejemplos podemos citar las representaciones de Aquiles en Esciros, donde, como paradoja, oculto a la mirada de extraños en el gineceo del palacio del rey Licomedes en Esciros, destaca la figura de Aquiles, quien, mediante el recurso de personajes que dirigen su mirada hacia él, siente, no obstante, ante la estratagema de Odiseo, la llamada del deber y, por tanto, la asunción de su fatal destino. Una decisión que aparece reflejada captando al héroe en el instante previo a tomar las armas y, en concreto, el escudo, o en el mismo momento de enarbolarlo (Neira, 2012).

A este respecto, en algunas pinturas pompeyanas y en el mosaico parietal -in situdel ninfeo de la domus de Apolo también en Pompeya, de mediados del siglo I d. C.,

2 Acerca del profundo sueño en el que aparecen sumidas algunas representaciones femeninas como estrategia para eliminar cualquier atisbo de su responsabilidad o consentimiento, ya nos hemos pronunciado en Neira, 2011. 
la representación del escudo con el centauro Quirón instruyendo al joven Aquiles, refuerza de modo subliminal, que la decisión de Aquiles es en realidad la renuncia a aquel travestismo que, como fémina, Arminda o Pirra, según los autores, le mantenía en el gineceo, bajo la protección y la seguridad de la esfera doméstica, y significa el regreso consciente a su verdadero yo, la asunción de su auténtico papel y, en definitiva, de su trágico destino (Ghedini, 1997).

Un destino fatal e ineludible en el transcurso de la Guerra de Troya que se adivina igualmente en las imágenes de otros célebres mosaicos al contemplar al héroe enarbolando el escudo (Neira, 2012).

En suma, miradas de complicidad (Europa), sueños que revelan la inconsciencia y la ausencia de responsabilidad (Ilia/Rea Silvia), miradas prohibidas, y sus fatales consecuencias, como medio de control social (Acteón), miradas que dirigen nuestra atención hacia el protagonista (Aquiles). En todas ellas, es protagonista tanto quien mira como quien es mirado.

Sin olvidar la mirada de sí mismo, la que, por su significado a través del análisis de las representaciones de la propia imagen reflejada, en particular en un espejo o en el agua, aluden a la mismidad y la alteridad.

Es el caso de Afrodita/Venus, en escenas denominadas del Triunfo, en concreto aquellas en las que la figura de la diosa es recreada en el instante de su denominada «toilette» (Neira, 2012a), donde una cuestión es la imagen en sí misma y otra lo que el espectador ve a través de ella, contraponiéndose la estética y la fantasía, la objetividad y la subjetividad, la realidad y la ilusión. Y en esta línea, el reflejo desvela la realidad o la falsedad, la propia identidad o el descubrimiento de lo «otro», la mismidad y alteridad. Puede decirse, por tanto, que la imagen reflejada es un dispositivo de evocación, es un emblema de todo aquello de lo que vemos sin ver y, a la vez, de lo que querríamos ver y no vemos (López Monteagudo, 2013, 206-208, fig. 31), de las nereidas y de algunas representaciones que, como un fenómeno muy significativo en la Antigüedad Tardía, reproducen la imagen de una domina en el escenario doméstico de sus posesiones recibiendo las ofrendas de sus sirvientes y en particular en plena «toilette» junto a sus doncellas, en actitudes más propias de la iconografía de determinadas divinidades femeninas, como Venus, por ejemplo en un pavimento de las termas de la villa de Sidi Ghrib, en las cercanías de Carthago, en torno a principios del siglo V d. C. (Neira, 2011, 7-11).

En estrecha relación con la imagen reflejada, la contemplación del propio rostro reflejado, sin embargo, no siempre agrada a quién se mira, tal y como nos recuerdan algunos autores antiguos (Ovidio, Metamorfosis, VI, 383-385; Ovidio, Fasti, VI, 695- 
709; Higinio, Fabulas, 165) al relatar un episodio atribuido a Atenea, quien habría desechado la idea de tocar la flauta al contemplar su rostro deforme en el agua, con los carrillos hinchados ${ }^{3}$, según se documenta en un mosaico del siglo IV d. C., hallado en Kelibia (Túnez) que se conserva en el Museo de Nabeul (Blanchard-Lémée et al., 1995). Es posible que este episodio, sobre el rechazo de Atenea hacia una parte de sí misma, simbolice ese conflicto permanente en el ser humano entre la mismidad y la alteridad.

En relación todavía con el reflejo de uno mismo en el agua, pero con diferente desenlace, es preciso retornar de nuevo a la leyenda del baño de Artemisa/Diana, que, entre otros autores, nos ha sido transmitida también por Ovidio (Metamorfosis, III, 138-252) y por Higinio en dos de sus Fabulas (Fabulae, 180-181). A este respecto, ambos coinciden en señalar que en el transcurso de aquel célebre baño en la fuente llamada Partenia,

mientras allí se lava la Titania en su acostumbrada linfa, he aquí que el nieto de Cadmo, diferida parte de sus labores, por un bosque desconocido con no certeros pasos errante, llega a esa floresta: así a él sus hados lo llevaban. El cual, una vez entró, rorantes de sus manantiales, en esas cavernas, como ellas estaban, desnudas sus pechos las ninfas se golpearon al verle un hombre (Ovidio, Metamorfosis, III, 174-176),

o más escuetamente «se puso a la vista de la diosa» (Fabulae, 181, 1) Acteón y fue descubierto por ella y las ninfas que la acompañaban.

No obstante, en el mosaico tunecino de Thaenae (Blanchard-Lémée, 1995) de fines del siglo III, que se conserva en el Museo de El Bardo, o en el mosaico argelino de las Termas Filadelfis de Timgad, que se fecha ya a fines del siglo IV o comienzos del V (Germain, 1969, 19-23, lám. VII), el descubrimiento y el sobresalto de la diosa se produce al contemplar no su voluptuoso cuerpo al desnudo reflejado en el agua, sino el reflejo de la imagen de Acteón, que, escondido y agazapado en las alturas de la caverna, se había quedado extasiado como un auténtico «voyeur».

Sin embargo, el episodio más emblemático en torno a la imagen reflejada es la conocida leyenda de Narciso, cuya fuente literaria más antigua de las conservadas se documenta, 50 años antes que el texto de Ovidio (Metamorfosis, III, 339-510), en un

3 Higinio ofrece algunos detalles más en su obra (Fabulae, 165) : «Se dice que Minerva fue la primera que fabricó un aulós con huesos de ciervo y acudió a un banquete de los dioses para tocarlo. Juno y Venus se burlaron de ella, porque al hinchar los carrillos se le había puesto la cara azulada. Como la habían visto fea y se habían burlado de ella al tocar, fue al bosque de Ida a una fuente; se puso a tocar allí y, mirándose en el agua, vio que se habían burlado de ella con razón. Por eso tiró el aulós y, maldiciéndolo, deseó que cualquiera que lo cogiera sufriera un grave castigo ...». Este no sería otro que el pobre Marsyas, representado ya en plena competición con Apolo en numerosas pinturas de vasos griegos y otros soportes, quien tanto por la maldición de Atenea como por la osadía de competir con Apolo sería castigado a morir desollado colgado de un árbol, según refiere también Ovidio en otro pasaje (Metamorfosis, VI, 383-). 
Papiro de Oxirrinco, descubierto en 2004. Ambos textos mencionan la insensibilidad de Narciso al amor de numerosos jóvenes y ninfas ${ }^{4}$, afligidos por el desprecio del joven, quien, como es sabido, finalmente habría de caer rendido ante el reflejo de su propio rostro en el agua de una fuente.

Ovidio describe que, a la vista de aquella imagen, se queda «como una estatua esculpida en mármol de Paros» y, lo más significativo, cree que es otro, enamorándose locamente de una imagen de la que ignora el nombre y la naturaleza. De hecho, Narciso afirma entre fascinado y destrozado «Soy seducido, yo veo, pero lo que veo no lo puedo asir», si bien finalmente termina dramáticamente por reconocerse, cumpliéndose entonces la profecía de Tiresias, cuando, a la pregunta de su madre, la ninfa Liriopé sobre la duración de la vida de su hijo, el adivino contestó que el niño vivirá largos años y tendrá una vejez prolongada siempre que no se conozca: si se non noverit (Ovidio, Metamorfosis, III, 346-350).

La imagen reflejada nos da la imagen real y la imagen soñada, la mismidad y la alteridad. Pero también el plano del tiempo, porque la imagen reflejada no es tanto la imagen del presente, como la evocación del pasado, de otra identidad, o la emoción del futuro (López Monteagudo, 2013).

No obstante, al abordar la mirada en el mito, destaca sobre todas las antes citadas la leyenda de Medusa, como representativa de aquella mirada en sí misma fatal, que es preciso eludir a riesgo de quedar petrificado, una hazaña solo conseguida por Perseo, gracias a la inestimable ayuda de los dioses, de Hermes y, en particular, de Atenea. Y a consecuencia, la mirada que se transforma y se convierte en apotropaica.

Se trata de una mirada que, de modo extraordinario, al petrificar simboliza lo marginal, al otro, al mundo ajeno al ordenado mundo griego, y por tanto, sus estratagemas para evitarla el triunfo de la civilización. En cierto modo la leyenda combina la mirada de fatales consecuencias y aspectos de la mirada a través de imágenes reflejadas, pues si los autores antiguos mencionan el efecto petrificante y mortífero de la mirada de Medusa, el episodio relativo a la estratagema urdida para su decapitación incluye elementos propios de las imágenes reflejadas, al eludir Perseo su mirada, mirando la imagen de Medusa reflejada en el escudo para atinar en la decapitación:

4 Entre todos los despreciados destaca Eco, mencionada también por Nonnos de Panopolis, autor del siglo V d. C. en sus Dionysiacas. Eco aparece en algunas pinturas pompeyanas y en uno de los mosaicos de Antioquía, identificados ambos por su nombre, y de un eros con una antorcha, haciendo referencia al amor no correspondido de la joven y al castigo que, por este motivo, los dioses imponen a Narciso, que es enamorarse de la imagen reflejada en el agua, lo que le conducirá a la muerte. Si bien es más frecuente la representación única de Narciso en otra serie de pinturas pompeyanas y en la mayoría de los mosaicos documentados, que parecen evocar los siguientes versos de Ovidio. 
Perseo se detuvo junto a ellas aún dormidas y, guiada su mano por Atenea, volviendo la mirada hacia el escudo de bronce en el que se reflejaba la imagen de la Gorgona, la decapitó ... Perseo guardó la cabeza de Medusa en el talego y emprendió el regreso. Las otras Gorgonas despertaron de su sueño y lo persiguieron, pero no podían verlo pues iba cubierto con el yelmo (Apolodoro, Biblioteca, II, 4, 3).

Respecto a la consideración de Medusa y sus hermanas las Gorgonas como pertenecientes al mundo marginal, dominado por la barbarie, son sumamente reveladoras las referencias de algunos autores antiguos acerca del espacio geográfico en el que las tres hermanas habitaban, si bien no coinciden de modo preciso en la denominación del lugar.

Cerca de las Hespérides, según Hesíodo (Theog., 274), quien nos revela además algunos de los datos más significativos de Medusa, su unión con Poseidón, la propia decapitación y los «seres» a los que dio a luz:

[...] y a las Gorgonas que viven al otro lado del ilustre Océano, en el confín del mundo hacia la noche, donde las Hespérides de aguda voz: Esteno, Euríale y Medusa desventurada; ésta era mortal y las otras inmortales y exentas de vejez las dos. Con ella sola se acostó el de Azulada Cabellera en un suave prado, entre primaverales flores. Y cuando Perseo le cercenó la cabeza, de dentro brotó el enorme Crisaor y el caballo Pegaso. A éste le venía el nombre del que nació junto a los manantiales del Océano, y a aquél porque tenía en sus manos una espada de oro. [...] monstruo extraordinario, en nada parecido a los hombres ni a los inmortales dioses, tuvo Medusa en una cóncava gruta: la divina y astuta Equidna, mitad ninfa de ojos vivos y hermosas mejillas, mitad en cambio monstruosa y terrible serpiente, enorme, jaspeada y sanguinaria, bajo las entrañas de la venerable tierra (Hesíodo, Teogonía, 295-301).

Sobre la localización de Medusa y sus dos hermanas, las Gorgonas, Píndaro (Pin., Piticas, X, 30-50) las sitúa cerca de los Hiperbóreos, Esquilo (Aesch. Prometeo, 791) en Cístene, Diodoro Sículo (Biblioteca Histórica, 3, 52, 4) en las regiones del oeste de Libia, más allá de las fronteras del mundo civilizado, Lucano (Farsalia, 9, 619) en los últimos confines de Libia, allí donde la tierra ardiente se une con el océano; donde los campos están desprovistos de árboles y plantas, sin cultivo, pero llenos de rocas resultado de la mirada de su reina, mientras Virgilio (Eneida, VI, 390-396) refiere que la Gorgona habita en la entrada del Orco, con otros monstruosos seres.

Más allá de su ubicación concreta en el extremo occidente, según la interpretación tradicional del mito, la idea de la decapitación de Medusa habría sido una estratagema de Polidectes para alejar al joven Perseo de la isla de Sérifos con el fin de lograr la mano 
de su madre, Dánae. Sin embargo, otra versión referida por Apolodoro menciona que, ante la dificultad de obtener la mano de su amada Dánae, Polidectes había solicitado a sus amigos regalos para concurrir a la mano de Hipodamía, dándose en este contexto el atrevimiento del ingenuo Perseo, quien le habría asegurado que, si se lo pedía, podría traerle la mismísima cabeza de la mortal de las Gorgonas:

El hermano de Dictis, Polidectes, que era rey de Sérifos, se enamoró de Dánae, pero ante la dificultad de yacer con ella porque Perseo era ya adulto, convocó a sus amigos y con ellos a Perseo diciéndoles que reunieran regalos de boda para Hipodamía, hija de Enómao. Al decir Perseo que no vacilaría ni ante la cabeza de la Górgona, Polidectes pidió a los demás que buscasen caballos, pero de Perseo no aceptó caballos sino que le ordenó traer la cabeza de la Gorgona (Apolodoro, Biblioteca, II, 4, 2).

La versión que nos transmite Apolodoro nos recuerda a aquella leyenda en torno al encuentro de Pelias y Jasón, en cuyo transcurso habría tenido lugar, a instancias de Pelias, la formulación de una estratagema para alejar a un rival que pretendiera apoderarse de su trono. Como se recordará, Jasón le respondió a Pelias que, en ese caso, él enviaría a su oponente a la búsqueda de una misión imposible, el vellocino de oro. Y del mismo modo que a continuación Pelias le encargó a Jasón la recuperación del célebre vellocino de oro, Polidectes habría tomado buena nota de la idea de Perseo, encomendándole otra misión «imposible», la decapitación de Medusa.

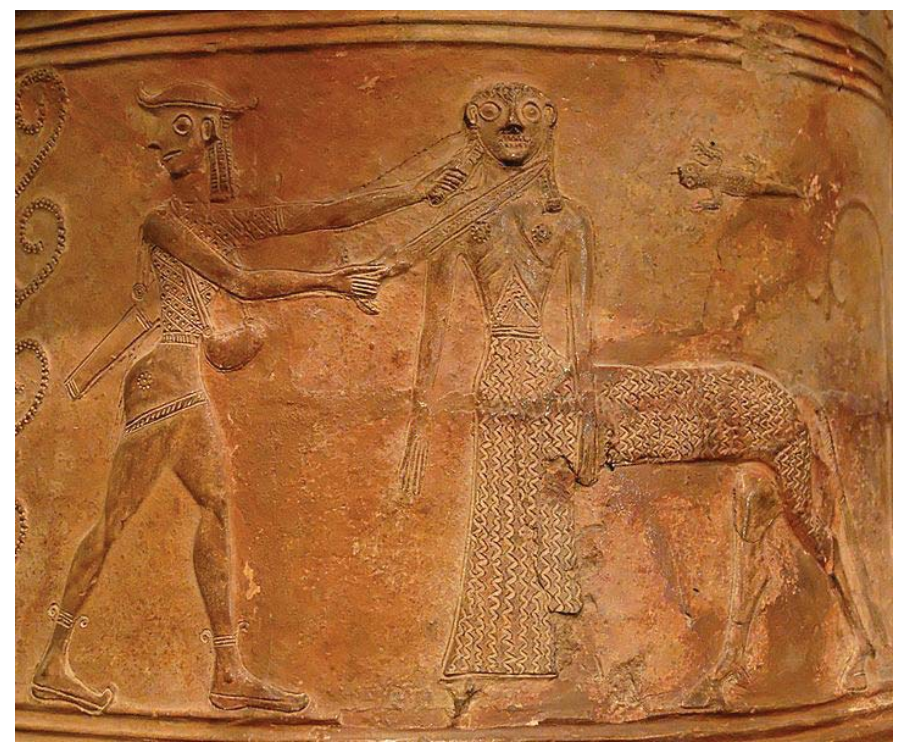

Fig. 1. Ánfora beocia, 670 a. C. Musée du Louvre, París.

Según J. Boardman (2001), The history of Greek Vases, Londres, lám. 47. 
Al mencionar los detalles y peligros de tal gesta, el propio Hesíodo en otra de sus obras (Escudo, 223-224) alude a los rasgos horribles de las Gorgonas, como fiel reflejo de la representación de la barbarie: «[...] Detrás de él, las Gorgonas horrendas e indecibles se precipitaban ansiosas de cogerle ... », tal y como se documenta en las representaciones más antiguas de la pintura de vasos de época arcaica, en concreto en la plasmada en un ánfora beocia, fechada en torno al 670 a. C. y conservada en el Museo del Louvre (Fig. 1) en la que Perseo aparece decapitando a una Medusa mitad humana, mitad animal, y en otras muchas en las cuales Medusa figura representada con cara horripilante y grotesca, como en el olpe del Pintor de Amasis, fechado hacia el 550 a. C., en el que Perseo decapita a una Medusa alada con cuerpo humano y cabeza monstruosa, boca y ojos amplios, dientes grandes, largos y afilados colmillos, lengua repelente y serpientes en la cabeza y en la cintura.

Un aspecto que evocan también siglos después Apolonio de Rodas (Argonaúticas, IV, 1515) al referirse al retorno triunfal de Perseo, tras conseguir la hazaña, «llevando al rey la cabeza recién cortada de la Gorgona, todas las gotas de negra sangre que cayeron al suelo hicieron germinar la especie de aquellas serpientes», y Ovidio (Metamorfosis, IV, 735-) al describirnos el regreso de Perseo a su paso por Libia «[...] para no dañar con la dura arena la cabeza portadora de serpientes, mulle la tierra con hojas y extiende retoños nacidos bajo el agua y pone encima la cabeza de la Forcínide Medusa».

Píndaro (Píticas, XII, 15-20), no obstante, mencionaba a Medusa con el apelativo de «la de hermosas mejillas», preludiando la Medusa bella que siglos más tarde el mismo Ovidio nos describe en su Metamorfosis:

Ella era de una belleza resplandeciente y fue esperanza deseada por muchos pretendientes, y en toda ella nada hubo más notable que su cabellera; he encontrado a quien contara que él la había visto. Se dice que a ella la violó el soberano del mar en el templo de Minerva; se volvió y ocultó con la égida su casto rostro la hija de Júpiter, y para que esto no quedara sin castigo, convirtió en repulsivas serpientes la cabellera de la Górgona. También ahora, para aterrorizar a sus enemigos, que quedan paralizados por el miedo, lleva delante de su pecho las serpientes que ella produjo (Ovidio, Metamorfosis (IV, 753-790).

El relato de Ovidio es, por tanto, muy esclarecedor, al describir la belleza, en origen, y en concreto los hermosos cabellos de la joven Medusa, quien por su esplendoroso aspecto habría suscitado el interés y el deseo de numerosos pretendientes, entre los que se cuenta el mismo dios Poseidón, a cuya unión y descendencia hacía alusión Hesíodo, si bien Ovidio menciona explícitamente que dicha unión fue en realidad una violación en el espacio sagrado de un templo dedicado a Atenea, siendo la joven una víctima de la ira de la diosa y de su propia transformación, la de sus hermosos cabellos en horripilantes serpientes. 
Se trata de una leyenda que nos recuerda a la de la desdichada Escila de la Odisea (Hom. Odisea, XII, 101-110), igualmente relatada por Ovidio (Metamorfosis, XIII, 730-739), quien alude también a los orígenes de la monstruosa figura, tan joven y bellísima en tiempos que atrajo el deseo incluso de Glauco, una divinidad marina de la que la maga Circe estaba secretamente enamorada. A este respecto, habrían sido los celos de Circe y su despecho ante el rechazo de Glauco, perdidamente enamorado de Escila, las causas que habrían conducido a la maga a transformar la belleza de la joven en un ser monstruoso y despreciable, igualmente digno de ocultarse.

A este respecto, Atenea no sólo priva a Medusa de su belleza al transformarla en un ser monstruoso, sino que, al convertir su mirada en petrificante, logra el rechazo unánime de la Gorgona, pues, a partir de aquel episodio, nadie se atrevería ya a mirarla y admirarla por temor a quedar de inmediato completamente petrificado. En este sentido, como el destino más cruel, la otrora bella Medusa, presente en tiempos en territorios civilizados en tanto la leyenda de su violación transcurre en un santuario, es condenada a la exclusión, a salir del mundo civilizado.

Sin embargo, a pesar de esta expulsión, la rivalidad y los celos de Atenea debieron persistir, a juzgar por Apolodoro (Biblioteca, II, 4, 3) «[...] Algunos dicen que Medusa fue decapitada a causa de Atenea, pues esta Gorgona había querido rivalizar en belleza con ella», lo que explicaría que la diosa, no satisfecha con haberla transformado en un ser monstruoso y, en consecuencia, haberla desterrado a territorios al margen de la civilización, habría decidido después su muerte y, lo más sobresaliente, su apropiación como codiciado trofeo.

En este sentido, al describir el episodio de la decapitación de Medusa, se suele mencionar que Perseo contó con la ayuda inestimable, entre otros, de la propia diosa Atenea:

Ayudado por Hermes y Atenea, Perseo marchó al encuentro de las Fórcides ..., hermanas de las Gorgonas, viejas de nacimiento. Las tres disponían de un solo ojo y un solo diente, que compartían ... se lo devolvería si le indicaban el camino que llevaba hasta las ninfas. Estas ninfas tenían sandalias aladas y la kíbisis ... Las ninfas poseían además el casco de Hades ... cubierto con él veía a quién quería, pero era invisible para los demás. Con una hoz de acero recibida de Hermes llegó volando al Océano y sorprendió dormidas a las Gorgonas.

[...] Guiada su mano por Atenea, volviendo la mirada hacia el escudo de bronce en el que se reflejaba la imagen de la Gorgona, la decapitó ... Surgieron Pegaso y Crisaor ... las Gorgonas lo persiguieron, pero no podían verlo pues iba cubierto con el yelmo (Apolodoro, Biblioteca, II, 4, 3). 
El episodio narrado por Apolodoro aparece representado en el cuadro figurado de un mosaico romano hallado en Esparta (Panagiotopoulou, 1994), que constituye un unicum en la musivaria (Fig. 2). Además del joven Perseo en el centro de la composición, captado en el instante de decapitar a Medusa, en presencia de sus dos hermanas las Gorgonas Esteno y Euriale, mientras él mira en sentido inverso a la imagen reflejada en el escudo sostenido por Atenea, al mismo tiempo que de la cabeza a punto de ser decapitada nace efectivamente Pegaso, han sido incluidos varios epígrafes con los nombres en griego de Perseo, Medusa, Atenea, Pegaso y Libia, éste último en alusión a la personificación del territorio de Libia, donde se sitúa la hazaña en este pavimento. Llama la atención, no obstante, la inclusión de los nombres de personajes mitológicos tan conocidos, que al ser contemplados habrían de ser identificados sin posibilidad de error, máxime si se considera el protagonismo que alcanzaron no sólo entre los autores de época griega, sino de modo particular entre los escritores latinos y griegos de época romana como Ovidio y Apolodoro, entre otros. A este respecto, caben varias interpretaciones, desde la que plantea un contexto poco familiar a la leyenda, requiriendo epígrafes identificativos, aquella otra que pretende demostrar el conocimiento detallado del episodio, incluyendo hasta el lugar donde supuestamente habría sucedido, y hasta la que precisa de los nombres, bien conocidos, para reivindicar aspectos ligados a la simbología de la leyenda, quizás como expresión en otro contexto del conflicto entre civilización y barbarie, pues, a pesar de su origen griego, es bien sabido hasta qué punto los romanos habían asumido el legado helénico.

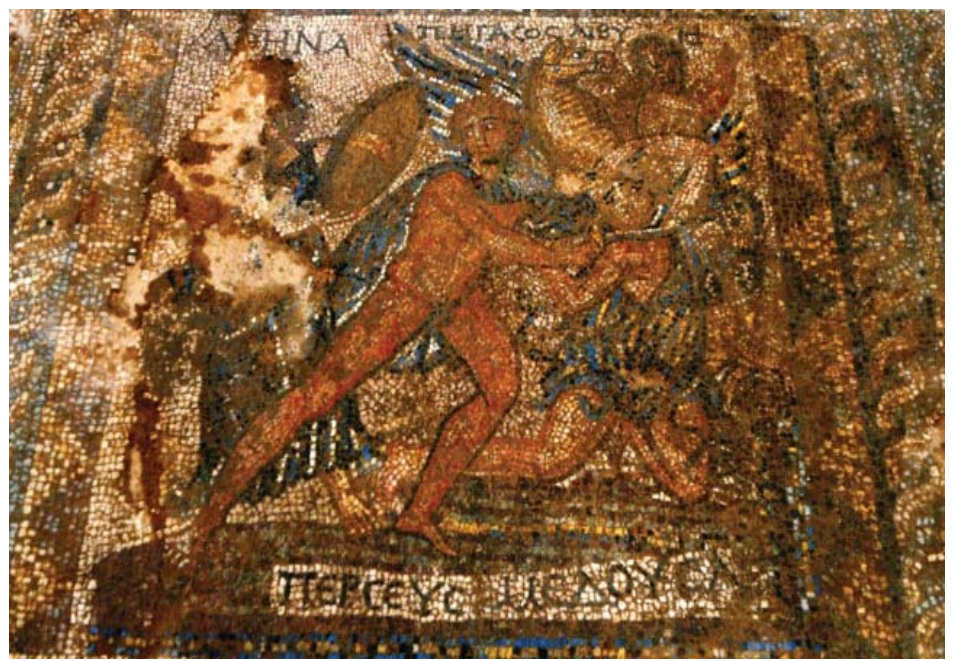

Fig. 2. Mosaico de Esparta, segunda mitad del s. III d. C., in situ. Según Panagiotopoulou, 1994. 
Retornando a la decapitación de Medusa, sería más correcto afirmar, a tenor del argumento que nos proporcionan las fuentes literarias y la propia iconografía, que Atenea habría sido la autora intelectual de la decapitación, mientras que Perseo su autor material, tal y como sucede en el episodio de la muerte de Aquiles, donde Apolo dirige y orienta la flecha disparada por Paris, y en innumerables episodios protagonizados por héroes, entre otros, por Odiseo y Eneas siguiendo los consejos de las divinidades.

En esta línea, sobre la «ayuda» fundamental de Atenea en tal hazaña, aunque en diferente contexto, Pausanias se hace eco de una versión proporcionada por un cartaginés, que mencionaba de modo explícito la ayuda de la diosa Atenea:

[...] Pero un cartaginés, Procles ... otra leyenda: en el desierto de Libia, una mujer de éstos que se extravió llegó a la laguna Tritónide y causó daño a sus vecinos, hasta que Perseo la mató. Al parecer, Atenea le ayudó en la empresa, porque los hombres en los alrededores de la laguna Tritónide están consagrados a ella (Pausanias, Descripción de Grecia, II, 21, 6).

Sin embargo, Pausanias es el único autor que, al referirse a Medusa, nos ofrece además otra versión, diferente, según la cual Perseo le habría dado muerte sin la intervención de Atenea. Según esta leyenda, tras la muerte de su padre, Medusa habría había heredado su trono, gobernando a sus súbditos cerca del lago Tritonide, en Libia, combatiendo con el mismísimo Perseo, príncipe del Peloponeso al mando de un gran ejército:

No lejos del edificio que está en el ágora de los argivos hay un túmulo de tierra; dicen que en él está la cabeza de la Gorgona Medusa. Aparte del mito, se dice con respecto a ella esto otro: que era hija de Forco, que después de morir su padre reinó sobre los que viven en los alrededores de la laguna Tritónide, que salía a cazar y que conducía a los libios en las batallas, y precisamente entonces, cuando con su ejército acampaba frente a las fuerzas de Perseo -a Perseo le acompañaban soldados escogidos del Peloponeso-, fue asesinada a traición de noche, y Perseo, admirando su belleza incluso después de muerta, le cortó la cabeza y la llevó para mostrarla a los griegos (Pausanias, Descripción de Grecia, II, 21, 5).

Aun a pesar de la decapitación, la mirada de la cabeza de Medusa mantiene intacta su capacidad de fulminar y petrificar. Así lo expresa, durante el regreso de Perseo, a su paso por el lugar en el que sostenía el cielo Atlas, formando el monte del mismo nombre, o por Libia, Ovidio, quien relata en otro episodio de la leyenda el origen del coral:

[...] para no dañar con la dura arena la cabeza portadora de serpientes, mulle la tierra con hojas y extiende retoños nacidos bajo el agua y pone encima la 
cabeza de la Forcínide Medusa. Los retoños, recién cortados y todavía vivos con su médula absorbente, se adueñan del poder del monstruo y se endurecen con su contacto y experimentaron en sus ramas y en sus hojas una nueva rigidez ... Ahora también se mantiene en los corales la misma naturaleza de coger dureza al contacto con el aire, y lo que era dentro del agua rama flexible se convierte en la superficie del agua en piedra (Ovidio, Metamorfosis, IV, 735-752).

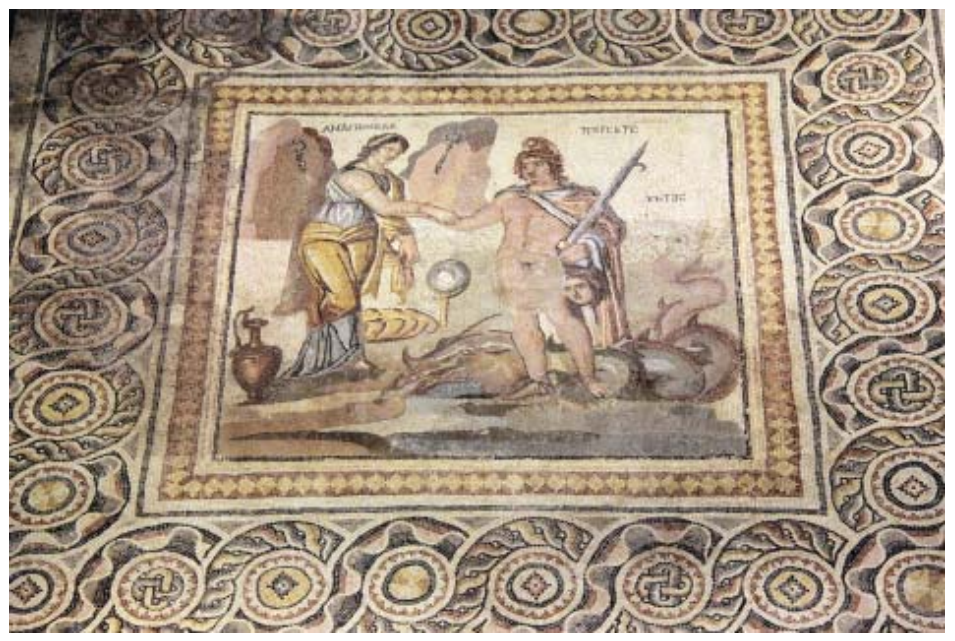

Fig. 3. Mosaico de Zeugma, primera mitad del s. III d. C. Museo de los Mosaicos, Gaziantep. Foto: Luz Neira.

En el transcurso de aquel retorno, sobrevolando Libia, Perseo contemplaría a la desdichada Andrómeda, recuérdese, encadenada y prisionera de un monstruoso ketos, en tanto víctima inocente del atrevimiento de su madre Casiopea, quien había osado competir en belleza con las nereidas en la leyenda conocida como «Juicio de las Nereidas $»^{5}$. A este respecto, Ovidio (Metamorfosis, IV, 695-) relata cómo en un enfrentamiento cuerpo a cuerpo con el monstruo, sin el uso de la infalible mirada de la hija de Forcis, habría conseguido liberar a la joven. Varias son las representaciones documentadas en pavimentos, donde, con el ketos ya vencido, el héroe aparece en el instante de liberar de sus cadenas a la inocente joven ${ }^{6}$ (Fig. 3). Sin embargo, entre otros autores, Luciano (Dialogos marinos, 14) precisa cómo Perseo fulminó al temible ketos

5 Episodio narrado por las fuentes literarias antiguas, entre las que destaca de nuevo Apolodoro (Biblioteca, II, 4, 3), donde se menciona la soberbia de Casiopea al pretender competir en un concurso de belleza con las nereidas más bellas, tales como Doris, Tetis y Galatea. El episodio fue plasmado también en tres mosaicos romanos de la parte oriental del Imperio, en Nea Paphos (Chipre), Palmira, y Apamea (Siria), cf. Neira, 2001, núm. 221 y ss.).

6 Incluso dándose significativamente las diestras, preludiando la dextrarum iunctio, propia del rito del matrimonio, que habría de celebrarse con posterioridad a esta hazaña, véase Neira, 2011; Bermejo, 2014. 
mostrándole tan sólo la cabeza de la Gorgona, certificando los poderes de Medusa incluso después de muerta, si bien tan sólo una de las representaciones musivas en las que se documenta este episodio refleja los poderes petrificantes de la cabeza de Medusa, una vez decapitada, en concreto en el cuadro figurado de un gran pavimento que cubría el gran corredor del peristilo de la domus de los Surtidores en Conimbriga (López Monteagudo, 1990), donde, junto al monstruo todavía vivo, Perseo le muestra la cabecita de Medusa (Fig. 4).

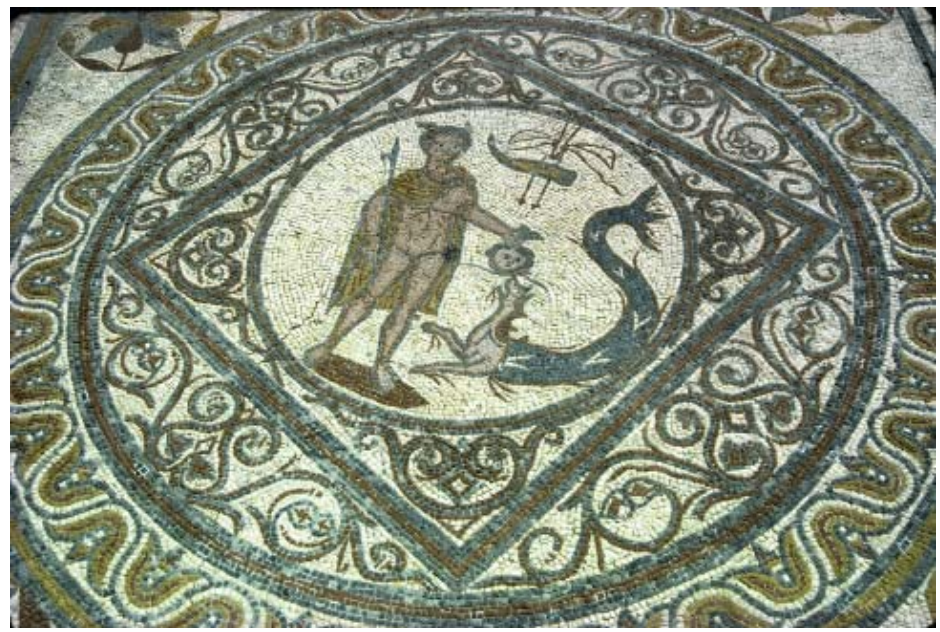

Fig. 4. Mosaico de la Casa de los Surtidores, Conimbriga, principios del s. III d. C., in situ. Foto: Luz Neira.

En la misma línea, al mencionar a Fineo -antiguo pretendiente de la joven Andrómeda con la que pensaba contraer matrimonio antes de su cautiverio, que sin haberse esforzado lo más mínimo en liberar a su prometida, reclama sus derechos sobre la joven- tanto Ovidio (Metamorfosis, V, 1-249), como Apolodoro (Biblioteca, II, 4,3 ) expresan «... mostrando la cabeza de la Gorgona a los confabulados los petrificó al instante». Y, de nuevo al regresar a Sérifos, al encontrarse con Polidectes y sus amigos: «y volviéndose les mostró la cabeza de la Górgona: cada uno de los que miraron quedó petrificado en la posición en que se encontraba ...»

Sin embargo, la acción más decisiva la protagoniza Perseo al entregarle a Atenea la cabeza de Medusa, según Apolodoro «mientras que la cabeza de la Górgona se la entregó a Atenea [...] Atenea insertó en medio de su escudo la cabeza de la Górgona» (Apolodoro, Biblioteca, II, 4, 3), propiciando en realidad la apropiación de la desdichada Medusa por parte de la diosa, que, efectivamente a partir de aquel gesto de Perseo, pasaría a ser-iqué paradoja!- el principal baluarte en la égida de Atenea. 
Recuérdese, así lo refiere Ovidio (Metamorfosis, IV, 789-790): «También ahora, para aterrorizar a sus enemigos, que quedan paralizados por el miedo, lleva delante de su pecho las serpientes que ella produjo». Y en tanto la cabeza de Medusa mantenía inalterable su facultad de petrificar a quien se atreviera a mirarla, la decisión de Atenea, de portarla en su pecho, aparece documentada en las representaciones de la diosa ya en la pintura de vasos desde la época arcaica, una iconografía cuya tradición se advierte también siglos después en los mosaicos, en los que particularmente junto a Hera y Afrodita la diosa aparece en las escenas del Juicio de Paris ${ }^{7}$. Así en un célebre pavimento de Caesarea (Blanchard-Lémée, 1995), en otro de Antioquía, conservado en el Louvre (Baratte, 1978, núm. 43), y en un pavimento de unas termas de Cos (De Matteis, 1999), así como en tres mosaicos hispanos, el de Casariche (Neira, 2010, 107-109, 130-134) y otros dos más recientemente descubiertos en Noheda (Cuenca) (Fig. 5) (Fernández Galiano, 2011, 175) y Castulo (Fig. 6) (Blázquez, 2014).

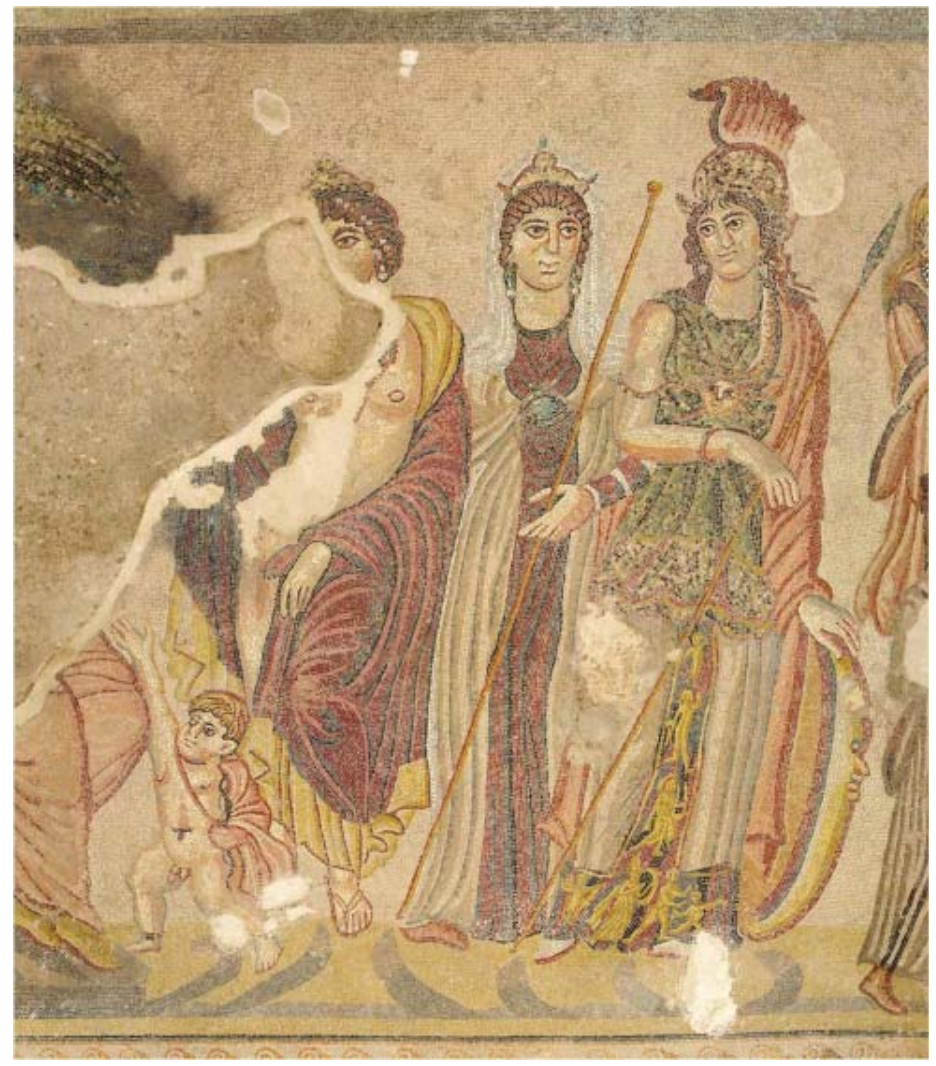

Fig. 5. Detalle del Juicio de Paris, mosaico de la villa de Noheda, finales del s. IV d. C., in situ. Foto: Cortesía José Latova, en Neira, 2012, fig. 55.

7 Tal y como ya señalábamos en López Monteagudo, Neira, 2010, 107-109. 


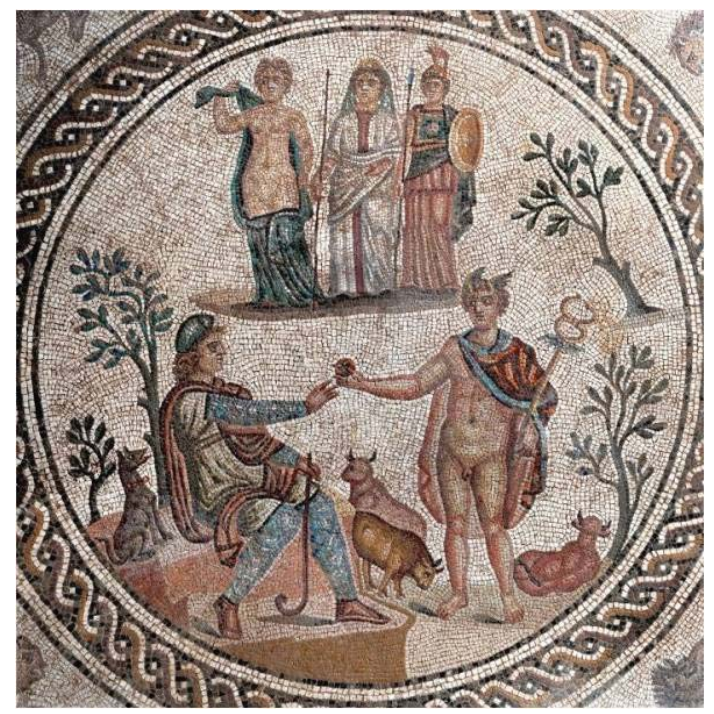

Fig. 6. Detalle del Juicio de Paris, mosaico de Castulo, finales del s. II-principios del III d. C., in situ. Foto: Luz Neira.

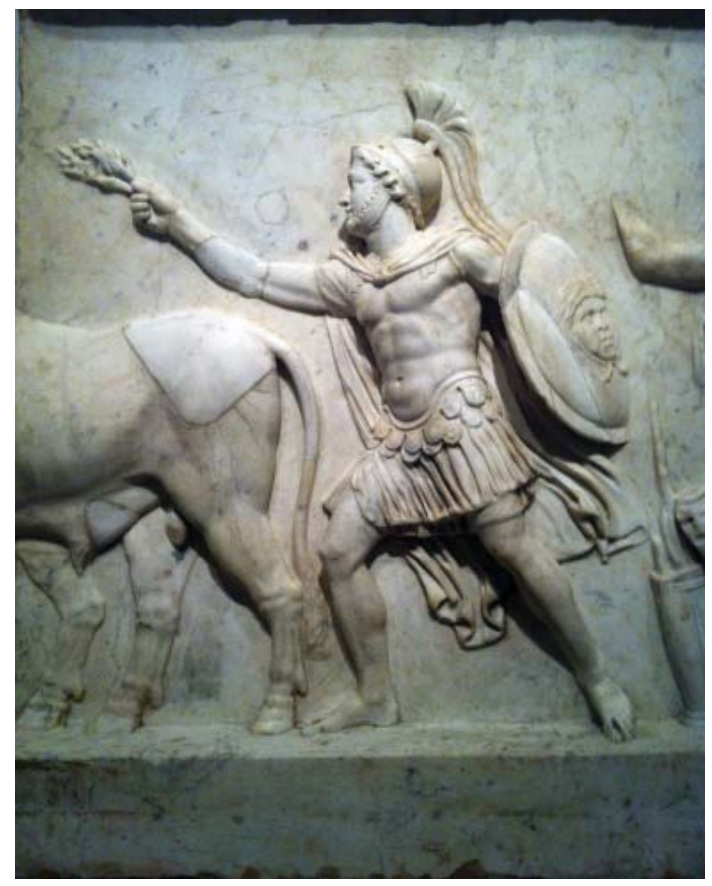

Fig. 7. Relieve de la época de Augusto, principios del s. I d. C. Musée du Louvre, París. Foto: Luz Neira. 
Esta decisión de Atenea que, a priori suponía el triunfo definitivo de la diosa sobre su desgraciada rival, inició no obstante el reconocimiento del carácter apotropaico de Medusa que a partir de este episodio pasaría de ser un monstruo confinado en lugares extremos, al que nadie quería ni debía mirar, a convertirse en preciado talismán contra los enemigos, portado, a imitación de la diosa, en su pectoral o coraza, e incluso también en los escudos y los cascos, por los más diversos héroes del ámbito mitológico y por los más célebres comandantes de la Antigüedad de muy diferentes épocas tanto en la órbita helénica, helenística y romana $^{8}$ (Fig. 7). Recuérdese a este respecto, la significativa representación de Alejandro Magno en el conocido mosaico de la Casa del Fauno de Pompeya, que se conserva en el Museo Nacional de Nápoles, donde el macedonio aparece en pleno combate contra su enemigo, el rey persa, portando en su pectoral la cabecita de Medusa, o el escudo decorado también con la cabeza de Medusa que porta uno de los personajes de una escena excepcional documentada en un mosaico hallado en los últimos años en Alter do Chao (Portugal) ${ }^{9}$ (Fig. 8).

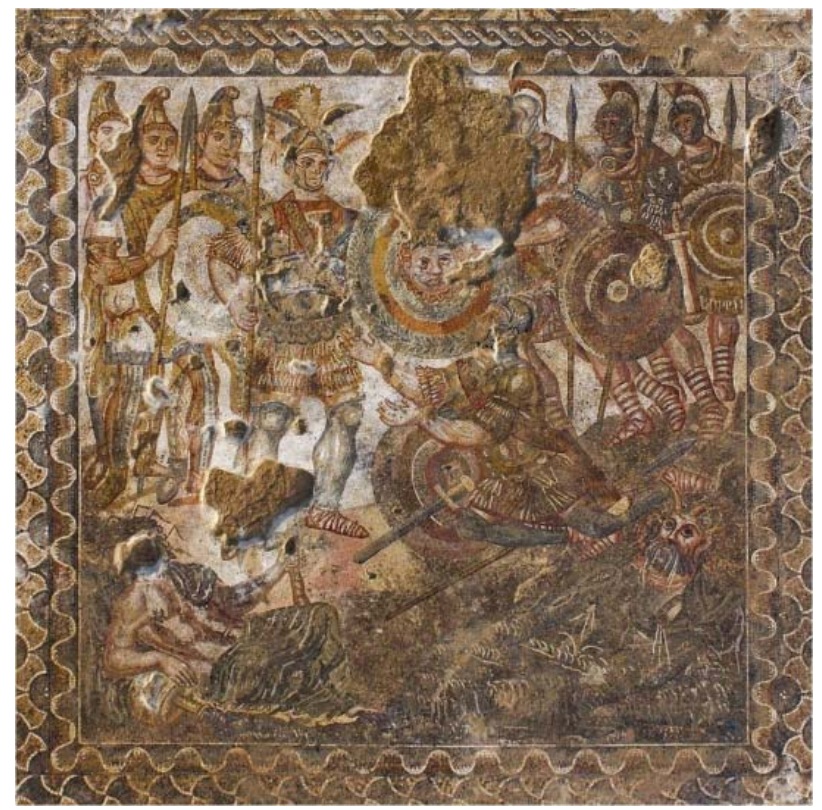

Fig. 8. Mosaico de Alter do Chao, s. III d. C., in situ. Foto: Cortesía Catia Mourao.

En esta línea, el valor apotropaico de Medusa excederá el ámbito estrictamente bélico, de tal modo, que, sin perder su «lugar» primordial en corazas y escudos a título individual, pasará también a ocupar y protagonizar con su presencia otros ámbitos

8 Sobre este particular, véase Vargas, 2013, 80-81.

9 Ibidem. 
de la esfera pública. Recuérdese a modo de ejemplo, entre las mejor conservadas, el Gorgoneion entre los intercolumnios del Foro de Leptis Magna (Fig. 9) en la Tripolitania (Libia), situados allí de modo majestuoso para proteger el espacio público, o las cabezas de Medusa, todavía visibles algunas en las grandes cisternas de Constantinopla (Fig. 10), al tratarse de un espacio digno de ser protegido ante los numerosos riesgos que podían entrañar las aguas.

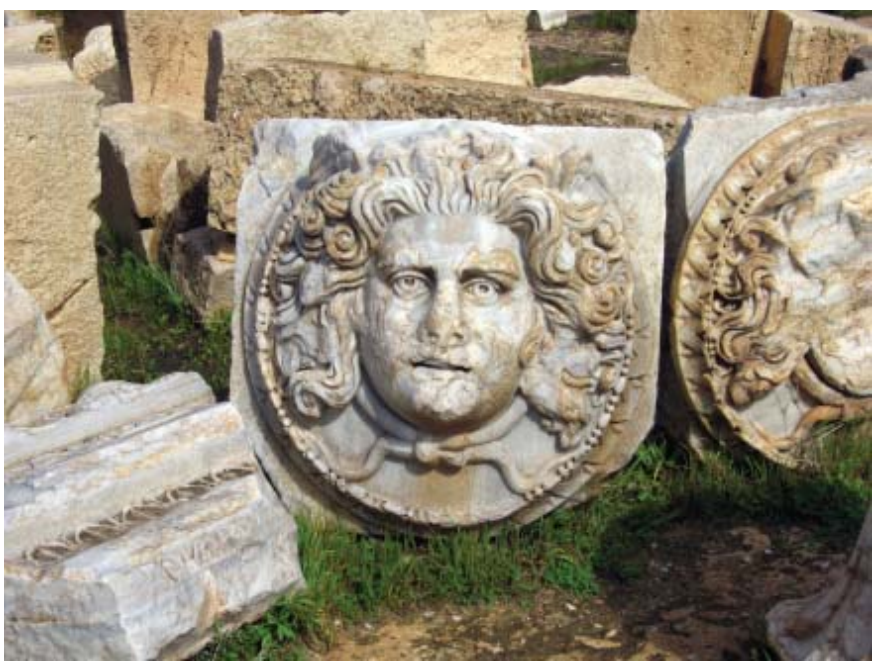

Fig. 9. Medusa en el Foro de Leptis Magna, principios del s. III d. C., in situ. Foto: Luz Neira.

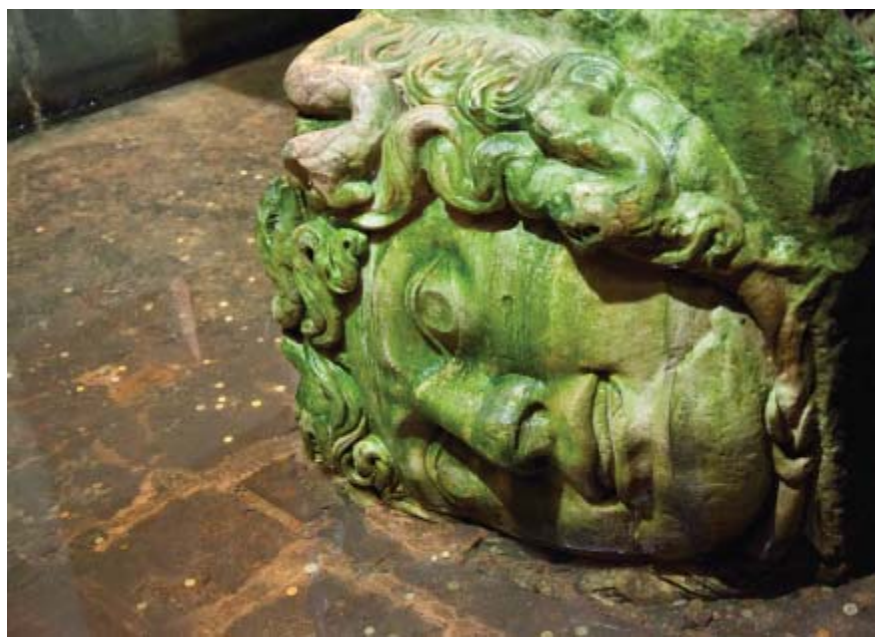

Fig. 10. Medusa en las cisternas de Constantinopla, s. IV d. C., in situ. Foto: @iStock.com/Burcin Tuncer. 
Más allá incluso de la esfera pública, el valor apotropaico de la cabeza de Medusa llegará además al ámbito doméstico, donde está representada en numerosos pavimentos de domus y residencias de villae documentados en todo el Imperio. No es de extrañar, si se considera el temor que, según los testimonios de las fuentes literarias antiguas, muchos romanos sentían ante el posible influjo de los malos espíritus, capaces de causar no sólo enfermedades, sino todo tipo de tragedias y males para los habitantes de la casa.

Por esta razón, el Gorgoneion destaca en el círculo central de numerosos mosaicos, que en un gran número pavimentaban las primeras estancias de acceso al interior de la casa para evitar de raíz la infiltración de los malos espíritus, gracias a la protección expresa de Medusa, cuya representación, según las creencias de quienes la seleccionaron, habría de disuadir y ahuyentar a quiénes pretendieran penetrar en el interior con malas intenciones.

Es la misma evolución que experimentaron otra serie de monstruos, en principio temidos de modo unánime, que después de haber sido «vencidos» y muertos por un héroe, adquieren mediante la representación de su figura un carácter apotropaico. Es el caso, por ejemplo, del Minotauro, aquel híbrido fruto de la pasión de Pasifae con el toro de Creta $^{10}$, que, encerrado en el Laberinto, era alimentado con la carne humana de jóvenes víctimas destinadas a tal fin, como pago de un tributo que debía rendir la Atenas de Egeo a la Creta de Minos. Sin embargo, una vez vencido y muerto a manos de Teseo, el Minotauro ${ }^{11}$, en ocasiones su cabeza, pasa a decorar el centro figurado, el cuadro central de un esquema geométrico, de algunos mosaicos que igualmente pavimentaban estancias de una domus, en particular, de nuevo, el vestíbulo, o un corredor del peristilo, con una finalidad estrictamente apotropaica, tal y como se documenta en la Casa de los Surtidores de Conimbriga (López Monteagudo, 1990).

Retornando a Medusa en los mosaicos, es preciso resaltar que, del mismo modo que el Minotauro se suele documentar en el único cuadro figurado, en el centro de un esquema geométrico identificado como representación del Laberinto, la cabeza de Medusa suele destacar en el círculo central inscrito en una composición geométrica que puede responder a varios modelos. Entre las más sencillas, la Medusa conservada en el Museo de Historia de Valencia (Fig. 11).

10 Recuérdese que la pasión de la esposa del rey Minos, Pasifae, por el toro de Creta habría sido inducida por los dioses. Según una versión por Poseidón y según otras por Afrodita.

11 Según Daszewski (1977, 38-39), mediante figuras simplificadas y simbólicas del Minotauro y el laberinto. 


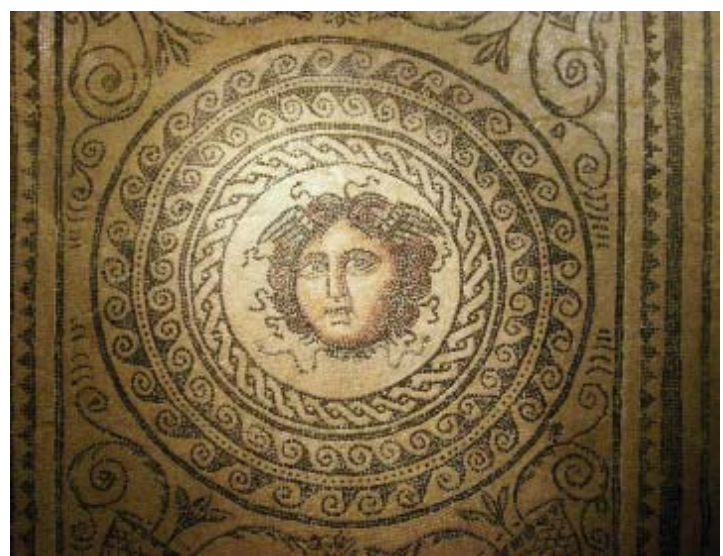

Fig. 11. Detalle del mosaico de Medusa, principios del s. III d. C. Museo de Historia de la Ciudad, Valencia. Foto: Luz Neira.

Una de las más difundidas, no obstante, es aquella denominada como roseta de triángulos curvilíneos (Luzón, 1988, 231), que se caracteriza por la disposición de anillos concéntricos compuestos por el mismo número de triángulos y cuya regla esencial es el aumento progresivo de su tamaño desde el interior hasta el exterior de la roseta $^{12}$. A este respecto, en el centro de un esquema similar, Medusa está documentada, entre otros, en los mosaicos de Carmona (Fig. 12), Alcolea del Río (Fig. 13), Malibú, Roma, Ostia y especialmente en mosaicos de Grecia, procedentes de Corinto (Fig. 14), Cnossos, Patras y Thasos (Neira, 1998, 230).

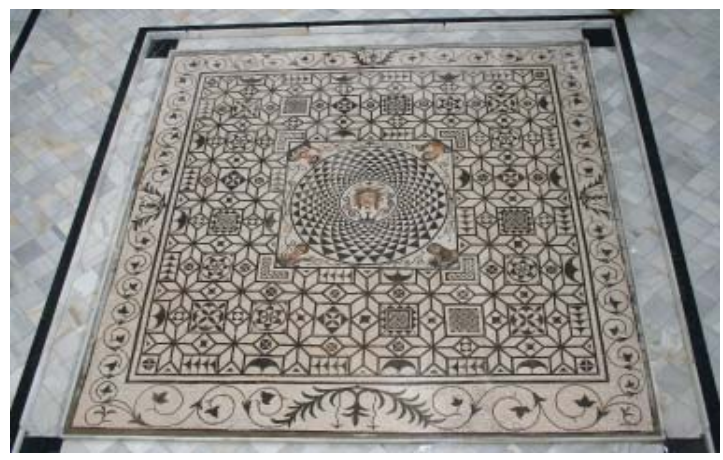

Fig. 12. Mosaico de Carmona, finales del s. II d. C. Museo Arqueológico de Sevilla. Según León, 2010.

12 Documentada antes del cambio de Era en Pompeya, fue muy frecuente en la musivaria itálica altoimperial, particularmente en la ostiense, aunque su difusión llega hasta el siglo VI d. C. En Hispania se documenta en mosaicos de los siglos II y III, en Ampurias, Itálica, Badalona, Linares, en varios de Mérida, Alcolea del Río, Écija y Carmona, siendo particularmente notable en Grecia, en dos mosaicos hallados en Patras, uno en Cnossos, otro en Thasos, y otro más en Mitilene y, con una rica policromía, en dos mosaicos hallados en el Pireo y Corinto (Luzón, 1988, 231; Neira, 1998, 230, 236). 


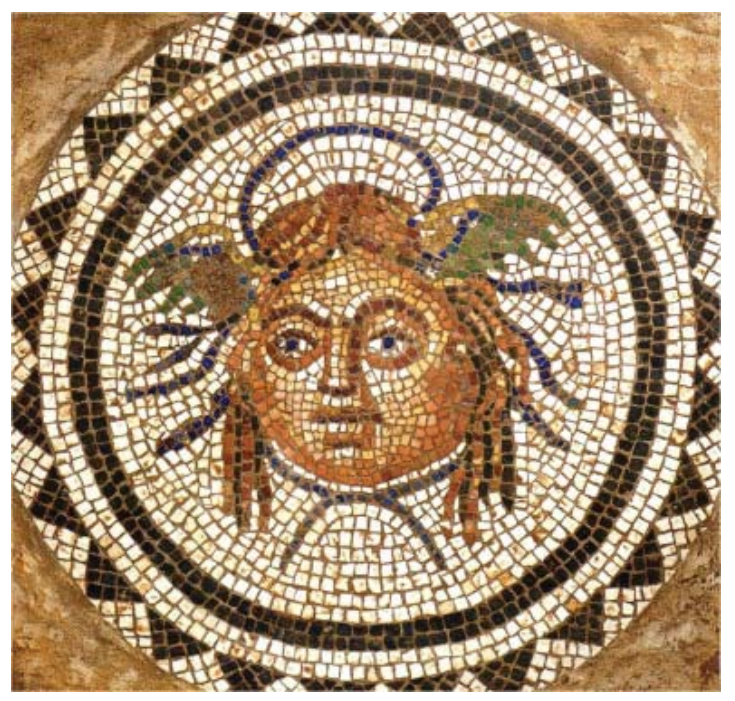

Fig. 13. Detalle de Medusa, mosaico de Alcolea del Río (Sevilla), principios del s. III d. C. Hispanic Society de Nueva York. Foto: Luz Neira.

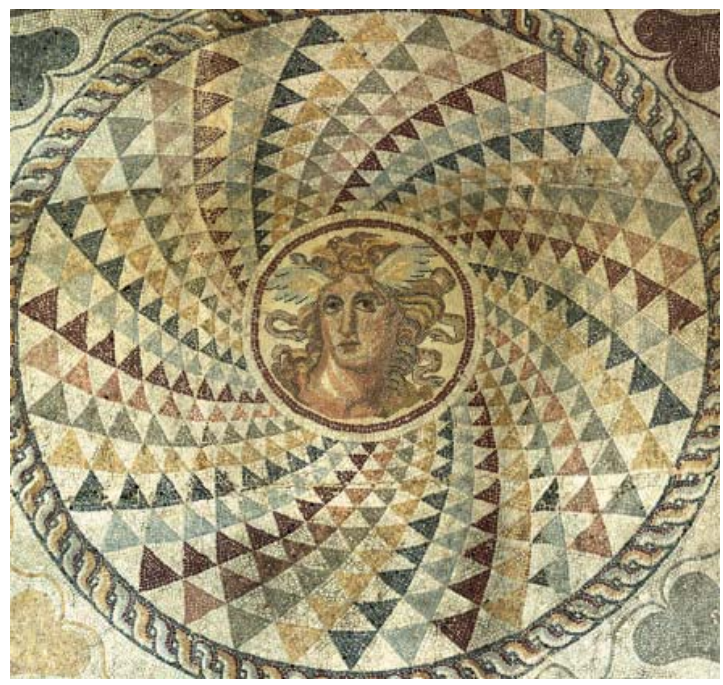

Fig. 14. Mosaico del Pireo, s. II d. C. Museo Nacional de Atenas. Foto: Luz Neira.

Asimismo Medusa decora también el círculo central que se inscribe en una composición muy similar, denominada como roseta de escamas, tanto bícromas como polícromas, siendo de destacar las de Alejandría, Rodas y Ptolemais (Fig. 15) (Panagiotopoulos, 1994, 369-370). 


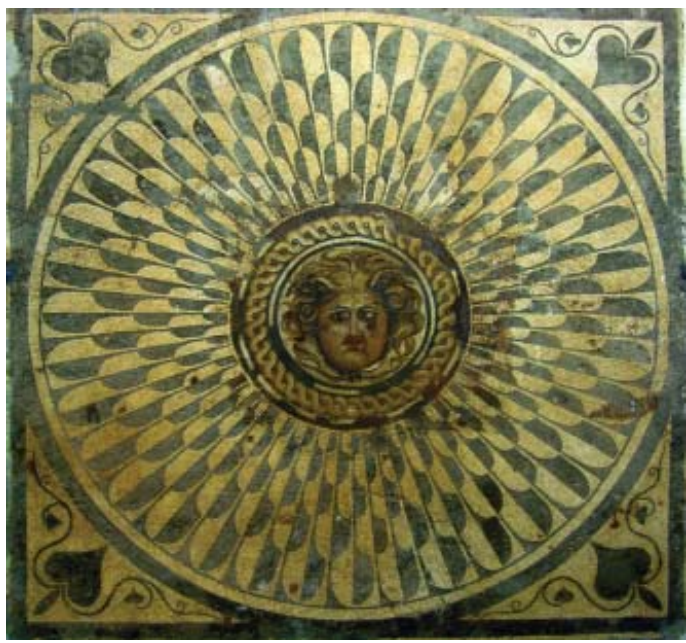

Fig. 15. Mosaico de Ptolemais, principios del s. III d. C. Museo de Ptolemais (Libia). Foto: Luz Neira.

Y por si fuera poco significativa en el mosaico la imagen de su rostro orientado generalmente hacia la entrada de la estancia (Mckeon, 1986), en ambas composiciones el efecto que reproduce la representación de la cabeza de Medusa en el centro de un esquema geométrico de forma circular ${ }^{13}$ parece evocar aquella ubicación en el centro de un escudo, concibiéndose en cierto modo el mosaico como un auténtico gorgoneion, un escudo protector de la estancia, sea de una domus en el ámbito urbano, sea de una residencia de una villa, o incluso de una sala termal, donde, en cualquiera de ellas, también la cabecita de Medusa está documentada en el interior de otras figuras geométricas, de carácter secundario, sin el protagonismo estelar de las citadas composiciones, en otras serie de pavimentos, como el mosaico de la villa suburbana de Alcolea (Córdoba), con varias representaciones de Medusa en los cuadros de lados curvos situados en una composición de esquema a compás con la loba y los gemelos en el círculo central (Blázquez, 1981, láms. 32-34)

Dada la evolución de Medusa, desde aquella mirada que petrificaba, y sin la pérdida de esta facultad, a una mirada apotropaica, el auge de su representación tanto en el ámbito individual, como en la esfera pública y privada en el transcurso de la Antigüedad es en cierto modo sinónimo de su regreso a la civilización, donde recupera un protagonismo que a su vez implica el olvido de su poderosa rival en las representaciones documentadas en diferentes soportes artísticos, hasta el punto de afirmar que finalmente Medusa, mirando y siendo mirada, habría conseguido superar en fama a la mismísima Atenea.

13 No obstante, inscrito en un cuadrado o rectángulo que se adecuara a la estancia de planta generalmente cuadrangular. 
Un análisis que, a tenor de las peculiares circunstancias de conservación de los mosaicos en su contexto originario, nos ofrece además otra mirada, en realidad, una doble mirada. Por un lado, una estrictamente visual, la de los usuarios de la estancia en la Antigüedad, y, por otro, una mirada más sutil y compleja, la ideológica y cultural de quién seleccionó y finalmente eligió una de estas escenas mitológicas para decorar el pavimento de una de las estancias de su domus en la ciudad o en la villa, contribuyendo a nuestra mirada sobre las creencias, temores y supersticiones de las elites en el Imperio Romano ${ }^{14}$.

\section{Bibliografía}

Apolodoro, Biblioteca (trad. y notas Rodríguez de Sepúlveda, M.), Madrid 1985.

Apolonio de Rodas, Argonaúticas (trad. y notas Valverde, M.), Madrid 1996.

Baratte, F., Catalogue des mosaïques romaines et paloechrétiennes u Musée du Louvre, París 1978.

Bermejo, J., Escenas de matrimonio: una aproximación al ritual nupcial romano a través de la iconografía musiva, en: Religiosidad, rituales y prácticas mágicas en los mosaicos romanos (coord. y ed. Neira, L.), Madrid 2014, pp. 11-22, figs. 2-12.

Blanchard Lémée, M. et al., Sols de l'Afrique romaine, París 1995.

Blázquez, J. M., Mosaicos romanos de Córdoba, Jaén y Málaga, Madrid 1981.

Blázquez, J.M., Mitos del mosaico de Cástulo, 7 Esquinas 6, 2014, pp. 109-112.

Daszewski, A., Nea Paphos II. La mosaíque de Thésee, Varsovia 1977.

De Matteis, L., I mosaici romani dell'area delle Terme occidentali, La Mosaïque GrécoRomaine VII (eds. Ennaïfer, M., Rebourg, A.), Túnez 1999, pp. 59-67, lám. VIII, 4-IX, 1.

Esquilo, Tragedias (trad. Fdez. Galiano, M., Perea, B.), Madrid 1986.

Fernández Galiano, D., El triunfo del amor en el mosaico de Noheda, en: Representaciones de mujeres en los mosaicos romanos y su impacto en el imaginario de estereotipos femeninos (coord. y ed. Neira, L.), Madrid 2011, p. 175.

Germain, S., Les mosaïques de Timgad. Étude descriptive et analitique, París 1969.

Ghedini, F., Achille a Sciro nella tradizione musiva tardoantica. Iconografia e iconologia, en: Atti del IV colloquio dell'Associazione Italiana per lo Studio e la Conservazione del Mosaico (eds. Carra Bonacasa, R. M., Guidobaldi, F.), Ravenna 1997, pp. 687-704.

14 No en vano las circunstancias de conservación del contexto originario para el que fueron destinados los mosaicos refleja las pretensiones e inquietudes, en suma, la ideología y las creencias de aquellos miembros de las elites urbanas y rurales que seleccionaron y eligieron finalmente estas representaciones de gran simbolismo, cf. Neira, 2009ª 11-53. 
Hesíodo, Obras y fragmentos (trad. Pérez Jiménez, A., Martínez, A.), Madrid 1997.

Higinio, Fabulas mitológicas (trad. Rincón, F.), Madrid 2009.

Homero, Odisea (trad. Pabón, J. M.), Madrid 2005 (reimp.).

León, P. (coord.), Arte Romano de la Bética III. Mosaicos, pinturas, manufacturas. Madrid 2010.

Lexicon Iconographicum Myhtologiae Classicae (LIMC) I, s. v. Acteón, Munich 1981.

López Montegaudo, G., El programa iconográfico de la Casa de los Surtidores en Conimbriga, Espacio, Tiempo y Forma 3, 1990, pp. 199-232.

López Monteagudo, G., San Nicolás, M. P., El mito de Europa en los mosaicos hispanoromanos. Análisis iconográfico e interpretativo, Espacio, Tiempo y Forma, Serie II, H. Antigua, t. 8, 1995, pp. 383-438.

López Monteagudo, G., Neira, L., Mosaicos, en: Arte Romano de la Bética III (coord. León, P.), Madrid 2010.

López Monteagudo, G., El desnudo reflejado, en: Desnudo y Cultura. La construcción del cuerpo en los mosaicos romanos (coord. y ed. Neira, L.), Madrid 2013, pp. 197 208.

Lucano, Farsalia (trad. Holgado, A.), Madrid 1984.

Luciano de Samósata, Obras I. Diálogos marinos (trad. Martínez, A.), Madrid 1996.

Luzón, J. M., La roseta de triángulos curvilíneos en el el mosaico romano, en: Anejos de Gerión I. Homenaje a García Bellido V, Madrid 1988, pp. 213-241.

Mckeon, C. H., Iconology of the Gorgon Medusa in Roman Mosaic, Michigan 1986.

Mourao, C., La Alquimia divina: Ejemplos de metamorfosis mágicas de la forma humana en mosaicos lusitanos, en: Religiosidad, rituales y prácticas mágicas en los mosaicos romanos (coord. y ed. Neira, L.), Madrid 2014, pp. 193-210.

Neira, L., Paralelos en la musivaria romana de Grecia e Hispania. A propósito de un mosaico de Alcolea del Río y un pavimento de Mitilene, Anales de Arqueología Cordobesa 9, 1998, pp. 223-246.

Neira, L., La representación del thiasos marino en los mosaicos romanos. Nereidas y tritones, Madrid 2002.

Neira, L., Los orígenes de Roma en la musivaria romana, en: IX Colloquio Internazionale sul Mosaico Antico (ed. Morlier, H.), Roma 2005, pp. 894-895.

Neira, L., Rea Silvia, Lexicon Iconographicum Mythologiae Classicae, Supplementum, 2009, p. 445.

Neira, L., La imagen en los mosaicos romanos como fuente documental acerca de las elites en el Imperio Romano, Estudos da Linguagem 7, 2009a, pp. 11-53. 
Neira, L., Representaciones de mujeres en los mosaicos romanos. El mito como argumento, en: Representaciones de mujeres en los mosaicos romanos y su impacto en el imaginario de estereotipos femeninos (coord. y ed. Neira, L.), Madrid 2011, pp. 7-36, 105-125.

Neira, L., Aquiles y la Guerra de Troya. La asunción del destino heroico, en: Civilización y barbarie. El mito como argumento en los mosaicos romanos (coord. y ed. Neira, L.), Madrid 2012, pp. 165-186.

Neira, L., The Sea thiasos of Nereids and Tritons in the Roman mosaics of Turkey, en: Mosaics of Turkey and Parallel Developments in the Rest of the Ancient and Medieval World. Questions of Iconography, Style and Technique from the Beginnings of Mosaics until The Late Byzantine Era (ed. Sahin, M.), Estambul 2012a, pp. 631655 y 59 figs.

Ovidio, Metamorfosis (trad. Álvarez, C., Iglesias, R.), Madrid 2001.

Panagiotopoulou, A., Représentations de la Méduse dans les mosaïques de Grèce, en: Colloquio Internacional de Mosaicos Antiguos VI, Guadalajara 1994, pp. 369-383.

Pausanias, Descripción de Grecia (trad. Herrero, M. C.), Madrid 1982 (reimp. 2009).

Píndaro, Odas y Fragmentos (ed. y trad. Ortega, A.), Madrid 1984.

San Nicolás, M.P., El modelo iconográfico de Ariadna y Rea Silvia adormecidas, en: Desnudo y Cultura. La construcción del cuerpo en los mosaicos romanos (coord. y ed. Neira, L.), Madrid 2013, pp. 49-58, figs. 54-59.

Vargas, S., Atenea y Medusa. Entre civilización y barbarie, en: Civilización y barbarie. El mito como argumento en los mosaicos romanos (coord. y ed. Neira, L.), Madrid 2012, pp. 69-82.

Virgilio, Eneida (trad. Echave, J.), Madrid 1992.

Wattel de Croizant, O., Les mosaïques représentant le mythe d'Europe (Ir-VIe siècles). Évolution et interprétation des modèles grecs en milieu romain, París 1995. 
Luz Neira

\section{Meduza $v$ rimskih mozaikih: od pogleda, ki okamni, do apotropejskega pogleda}

Ključne besede: antika, miti, pogled, Meduza, apotropejski značaj, rimski mozaiki, domus, villae

Ko govorimo o vlogi pogleda $\mathrm{v}$ mitu, ima med različnimi utelešenji pogleda $\mathrm{v}$ različnih mitoloških obdobjih poseben pomen Meduza, legenda o njenem pogledu, ki spreminja v kamen, pa je odražala pogled starih Grkov, njihov pogled na »drugega « kot ključ do mitološkega. Na ta način veliko razkriva tudi epizoda o preoblikovanju pogleda, ki je spreminjal $\mathrm{v}$ kamen, $\mathrm{v}$ nov, apotropejski pogled.

Kasneje je, zaradi simbolike tega mita, upodabljanje Meduze dobilo širok odmev $\mathrm{v}$ rimskem svetu, in sicer na različnih podlagah, na prav poseben način pa v mozaikih. Tako zaradi svojevrstnih okoliščin, v katerih so se mozaiki ohranili v svojem prvotnem kontekstu, analiza upodobitev Meduze na tlakovcih - gledamo jo in ona gleda nas, kakor je gledala, ko so njo gledali lastniki hiše, prebivalci in povabljeni, in skozi izmenjavo pogledov se $\mathrm{v}$ današnjem času izriše antika - priča o zavestni in želeni izbiri apotropejskega pogleda in o verovanjih $\mathrm{v}$ njegov pomen $\mathrm{v}$ domačem in zasebnem prostoru, bodisi $\mathrm{v}$ kontekstu domusa, bodisi znotraj ville. 


\section{Luz Neira \\ Medusa in Roman Mosaics: From the Gaze that Changes to Stone, to the Apotropaic Gaze}

Keywords: Antiquity, myths, regard, Medusa, apotropaic character, Roman mosaics, domus, villae

When we speak of the role of the gaze in myth, Medusa - and the legend of her gaze, which changes the viewer into stone - has a special significance among the various embodiments of the gaze in various mythological periods, for it expresses the view of the ancient Greeks and their regard of the "other" as a key to the mythological. In this way much is also unveiled through the episode about the transformation through the gaze, which transforms into stone, into a new, apotropaic gaze.

Thereafter, given myth's symbolism, representations of Medusa resounded through the Roman world, in various media, and very significantly in mosaics. Thanks to the conditions of conservation of mosaics in their original context, the analysis of representations of Medusa on pavements - in an exchange that today actualises the crossing of gazes which is thereby established between Medusa and the inhabitants of villas and their guests during the time of Antiquity - shows that in this apotropaic gaze there was a clear conscience choice linked to beliefs in private and domestic domains, be it in context of the domus, be it in within the villa. 